\title{
Citarum River Water Pollution and Stress Responses in The Tolerant and Sensitive Fish
}

\author{
Sunardia,d, Nadia Istiqomah $^{\mathrm{b}}$, Miranti Ariyanic ${ }^{\mathrm{c}}$ Kabul Fadilah $^{\mathrm{e}^{*}}$, Desak Made Malini ${ }^{\mathrm{a}}$, \\ Syifa Yolanda ${ }^{a}$, Azalea Putria ${ }^{a}$, Nining Ratningsih ${ }^{a}$
}

a. Department of Biology, Faculty of Mathematics and Natural Sciences, Universitas Padjadjaran, Jalan Raya Bandung-Sumedang Km. 21, Jatinangor, Sumedang 45363, Indonesia; sunardi@unpad.ac.id

b. Center for Environment and Sustainability Science, Universitas Padjadjaran, Jl. Sekeloa Selatan 1, Bandung 40132, Indonesia

c. Research Unit for Clean Technology, Indonesian Institute of Sciences (LIPI), Komplek LIPI Bandung, Jalan Sangkuriang, Gedung 50, Bandung 40135, Indonesia

d. Graduate Program on Environmental Studies, Postgraduate School, Universitas Padjadjaran, Jl. Dipati Ukur No. 35, Bandung 40132, Indonesia

e. Department of Environmental Engineering, Faculty of Engineering, Universitas Pembangunan Nasional "Veteran" JawaTimur, Jl. Rungkut Madya No.1, Surabaya 60294, Indonesia *Email: kabul.fadilah.tl@upnjatim.ac.id

Received 24 May 2021

Accepted 17 June 2021

Published 30 June 2021 DOI: https://doi.org/10.51264/inajl.v2i1.10

\begin{abstract}
Severe river pollution creates a stressful environment for aquatic organisms, causing disturbances to their health and leading to their extinction. Thus, in this study, the stress responses of tolerant (Oreochromis niloticus) and sensitive (Cyprinus carpio) fish to river pollution in the Citarum River, Indonesia were investigated. The two groups of fish were exposed to varying levels and lengths of water pollution, their blood was sampled, and stress responses were identified. The red blood cells (RBC) count, haemoglobin (HGB), haematocrit (HCT), white blood cells (WBC) count, blood glucose levels, and derived haematological indices such as mean corpuscular volume (MCV), mean corpuscular haemoglobin $(\mathrm{MCH})$ and mean corpuscular haemoglobin concentration (MCHC), were measured. Significant changes in these indices, with tendential changes in RBC and HCT, were observed, indicating that stress responses had occurred in both groups of fish. The sensitive fish recorded more pronounced changes in their haematological activities, with greater amounts of blood parameters being altered in response to water pollution exposure. This result suggested that the sensitive fish were more susceptible to environmental stressors and were, therefore, more vulnerable to extinction in a polluted natural environment.
\end{abstract}

Keywords: blood parameters, Citarum River, fish, river pollution, stress response.

\section{INTRODUCTION}

The Citarum River in West Java, Indonesia, covers an area of approximately 13,000 square kilometres, and is of vital importance to the water supply of both the Bandung and greater Jakarta metropolitan areas. Almost 10 million people reside in Bandung, with a further 25 million in greater Jakarta (Sunardi et al., 2012; Halpern et al., 2015; Borgwardt et al., 2019). The Citarum River provides as much as $80 \%$ of the surface water regulated by Jakarta's water supply authority, irrigates farms supplying 5\% of Indonesia's rice, and is a source of water for upwards of 2,000 factories (World Water Week, 2010). In an environmental context, the Citarum River harbours a variety of local fish, whose biodiversity maintains the stability of the broader ecosystem. These fish further support the animal protein needs of the local population or other services for humankind.

Currently, the global health of aquatic ecosystems is under extreme pressure from a wide range of anthropogenic contaminants, including pollutants derived from agricultural, mining, domestic, and industrial sources (Borgwardt et al., 2019; Halpern et al., 2015; Sunardi et al., 2012). The Citarum River is also 
experiencing severe water pollution and has been ranked among the most polluted rivers in the world (Cavelle, 2013). The river system is understood to suffer from numerous sources of pollution, which include a large quantity of suspended solids from the eroding catchment, industrial toxic effluents, domestic solid waste, untreated wastewater, and domestic sewage, agricultural pesticides and fertilisers, and animal waste loadings (Parikesit et al., 2005). Furthermore, the Blacksmith Institute has identified that levels of certain metals in the Citarum River are higher than the global average (Chanpiwat and Sthiannopkao, 2013).

Schäfer and Bundschuh (2018) and Gerber et al. (2017) have suggested that aquatic organisms can be affected at all levels of their biological organisation when exposed to waterborne contaminants. In terms of acute and chronic exposure, anthropogenic water contamination has been shown to result in adverse effects associated with the increased tissue burden of various pollutants (Amin and Hashem, 2012). The effects of water pollution on fish have further been shown to include immunosuppression, reduced metabolism, and damage to gills and epithelia (Bukola et al., 2015). In most situations, environmental stressors have been found to indirectly affect higher levels of the ecosystem hierarchy, such as populations and communities, and to directly affect molecular and cellular (sub-organism) level processes (Halstead et al., 2014). For organisms in the Citarum River, a quantitative risk assessment of trace metal contamination has demonstrated the chronic, additive, and unsustainable negative effects of metal mixtures in the aqueous environment (Sunardi et al., 2012).

Water pollution has caused many diseases and deaths worldwide and has become a major threat to freshwater biodiversity (Munir et al., 2016). A report has revealed that the number of species and the population sizes of fish in the Citarum River have decreased (Kartamihardja, 2019), and suggests that their extinctions relate to the deterioration of river water quality. Despite this, the processes underlying fish extinction are still questioned; thus, in order to develop more appropriate conservation plans, a more comprehensive understanding of the mechanism of water pollution induces species extinction is required. While such an understanding appears complicated to acquire, the most common and simple indicators, such as haematological parameters, offer a convenient point of departure for an initial investigation. Dal'Bó et al., (2015) showed that haematological profile represented an important indicator of health in fish, and could assist researchers in assessing their welfare. Lataretu et al. (2013) confirmed more specifically that the environment, especially water quality, could influence the following parameters in aquatic organisms: packed cell volume, red blood cell count, immature erythrocyte count, white blood cell count, and haemoglobin.

Fish vary in their traits, including in their behaviour, morphology, physiology, and genetic composition. As a result, their ability to cope with stressful environments has been shown to be species-specific (Balasch and Tort, 2019), and divisible into two groups in nature: tolerant and sensitive. The present study aims to understand the stress responses resulting from the exposure of these two groups of fish to the complex mixture of contaminants present in Citarum River pollution. To this end, Oreochromis niloticus was chosen as the more tolerant fish (Vicente and Fonseca-Alves, 2013; Rebouças et al., 2015), and Cyprinus carpio as the more sensitive one (García-Nieto et al., 2014). We expected that haematological indicators in the fish could explain differences in stress tension and health status, thereby furnishing important information to assist with riverine fish conservation.

\section{METHODS}

\section{Sampling Sites and Water Quality Assessment}

The Citarum River originates on the Wayang Mountain, about $40 \mathrm{~km}$ south of the Bandung metropolitan area, and flows north for approximately $270 \mathrm{~km}$ before discharging into the Java Sea. Its catchment area expands over several ecosystems that are both natural and anthropogenic, including forest, agricultural land, urban, and rural areas. Three cascade dams, Saguling, Cirata, and Jatiluhur, were established along the river to support the energy generation, irrigation, and water supply requirements of Java and Bali. For this study, four sampling sites were selected along the river course in the Bandung. Regency area that 
represented different levels of water pollution (Figure 1).

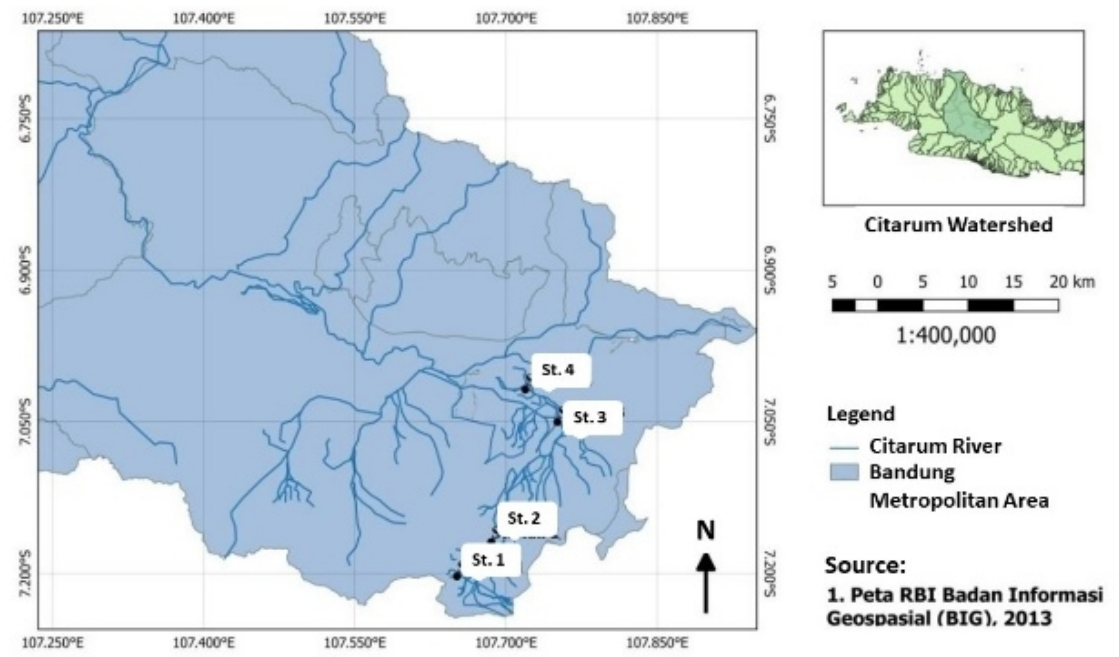

Figure1. Location of Sampling Sites

The first site, designated as 'Site One' (St.1) was located within the river's headwater tributaries on the Wayang Mountain and represented 'clean' water quality. Site 'Two' (St. 2), 'Three' (St. 3) and 'Four' (St. 4) were located in the Wangi Sagara, Majalaya, and
Sapan districts, respectively, and reflected increasing levels of water pollution, according to the following series: 'Site Two' was slightly polluted, 'Site Three' was fairly polluted, and 'Site Four' was heavily polluted.

Table 1. The Physico-chemical Characteristics of Polluted Water Samples from the Citarum River

\begin{tabular}{|c|c|c|c|c|c|}
\hline \multirow{2}{*}{ No. } & \multirow{2}{*}{$\begin{array}{l}\text { Physico-chemical } \\
\text { Parameters }\end{array}$} & \multicolumn{4}{|c|}{ Characteristics and Levels of Water Pollution } \\
\hline & & St. 1 & St. 2 & St. 3 & St. 4 \\
\hline 1 & Water Temperature $\left({ }^{\circ} \mathrm{C}\right)$ & 25.1 & 29.5 & 28 & 28.7 \\
\hline 2 & TDS $\left(\mathrm{mg} \mathrm{L}^{-1}\right)$ & 98 & 112 & 480 & 538 \\
\hline 3 & $\mathrm{TSS}\left(\mathrm{mg} \mathrm{L}^{-1}\right)$ & 22 & 53 & 55 & 48 \\
\hline 4 & Transparency (cm) & na & 28 & 35 & 28 \\
\hline 5 & Salinity (\%o) & 0.02 & 0.02 & 0.007 & 0.18 \\
\hline 6 & $\mathrm{pH}$ & 6.86 & 7.36 & 6.32 & 6.9 \\
\hline 7 & $\mathrm{DO}\left(\mathrm{mg} \mathrm{L}^{-1}\right)$ & 5.5 & 3.4 & 1.1 & 2.5 \\
\hline 8 & $\mathrm{NH}_{3}-\mathrm{N}\left(\mathrm{mg} \mathrm{L}^{-1}\right)$ & 0.002 & 0.009 & 0.024 & 0.023 \\
\hline 9 & $\mathrm{NO}_{3}-\mathrm{N}\left(\mathrm{mg} \mathrm{L}^{-1}\right)$ & 0.500 & 0.460 & 0.820 & 1.6 \\
\hline 10 & $\mathrm{NO}_{2}-\mathrm{N}\left(\mathrm{mg} \mathrm{L}^{-1}\right)$ & 0.014 & 0.061 & 0.022 & 0.025 \\
\hline 11 & $\mathrm{BOD}\left(\mathrm{mg} \mathrm{L}^{-1}\right)$ & 4.8 & 16.77 & 23.96 & 29.55 \\
\hline 12 & $\operatorname{COD}\left(\mathrm{mg} \mathrm{L}^{-1}\right)$ & 12.29 & 43 & 61.44 & 75.78 \\
\hline 13 & $\mathrm{PO}_{4}\left(\mathrm{mg} \mathrm{L}^{-1}\right)$ & 0.032 & 0.084 & 0.089 & 0.101 \\
\hline 14 & $\begin{array}{l}\text { Arsenic (As) } \\
\left(\mathrm{mg} \mathrm{L}^{-1}\right)\end{array}$ & 0.0028 & 0.001 & 0.0032 & 0.0031 \\
\hline 15 & $\begin{array}{l}\text { Mercury }(\mathrm{Hg}) \\
\left(\mathrm{mg} \mathrm{L}^{-1}\right)\end{array}$ & 0.00007 & nd & 0.00007 & 0.00014 \\
\hline 16 & Lead $(\mathrm{Pb})\left(\mathrm{mg} \mathrm{L}^{-1}\right)$ & 0.0451 & nd & nd & nd \\
\hline \multicolumn{2}{|c|}{ Score of Modified Pollution Index: } & 1.3 & 2.3 & 2.9 & 3.2 \\
\hline \multirow{2}{*}{\multicolumn{2}{|c|}{ Category: }} & Clean & Slightly & Fairly & Heavily \\
\hline & & Water & Polluted & Polluted & Polluted \\
\hline
\end{tabular}

Note: 'nd' denotes 'not detected' and 'na' denotes 'not available' 
Water samples were collected for physical and chemical analysis using a water sampler. The acidity $(\mathrm{pH})$, transparency, salinity and dissolved oxygen content (DO) of the samples were measured in situ, while water quality parameters, including the total dissolved solid content (TDS), total suspended solids content (TSS), biochemical oxygen demand (BOD), and the concentrations of ammonia $\left(\mathrm{NH}_{3}\right)$, nitrate $\left(\mathrm{NO}_{3}\right)$, phosphate $\left(\mathrm{PO}_{4}\right)$ and various heavy metals, were measured in the laboratory with reference to APHA (2005). The categorisation of water samples based on pollution level was performed with reference to a modified version of the 'Pollution Index' (Nemerow and Sumitomo, 1970). The physicchemical characteristics of the polluted samples are presented in Table 1.

\section{Test Fish}

Nile tilapia (O. niloticus) and common carp (C. carpio) were collected from a local fish hatchery in the East-Bandung area. The test fish were sized $12-15 \mathrm{~cm}$ in length and weighed 100-150 g. Fish of both sexes were used randomly. The fish were acclimatised to water quality and temperature in the laboratory for approximately one week prior to experiments. During this time of acclimatization and the subsequent phase, they were fed $5 \%$ of their body weight in fish pellets, daily.

\section{Experimental Design}

Forty-eight fish of each species were used in these experiments. The fish were separated into four groups for the four different levels of water pollution. Exposure experiments were conducted in test units consisting of a $30 \times 20.5$ x $20.5 \mathrm{~cm}$ glass tank containing the appropriate level of polluted water. Four fish individuals were transferred to each unit and were exposed for up to 14 days. Each experiment was replicated three times. Observations were made on days $0,3,7$, and 14 . For each observation, a fish individual was removed from the tank and sacrificed for haematological analysis.

\section{Hematological Analysis}

Following sacrifice, samples of blood, liver, muscle, and gill were taken from three fish specimens for each of the two species. The blood samples were collected in venojek tubes by puncturing fish caudal vessels with a sterile syringe. RBC and WBC counts were measured under a light microscope with an 'Improved
Neubauer' haemocytometer. HGB concentration was measured using a Sahli haemoglobinometer. Blood glucose concentration was determined using accu-check active glucose meters. The microhematocrit method was used to determine HCT levels. The work of Woodman and Tharp (2002) was used as a reference for the calculation of all of the above blood parameters. For calculation of the derived haematological indices of $\mathrm{MCV}, \mathrm{MCH}$, and $\mathrm{MCHC}$, the following standard formulae described by Turgeon (2005) were used:

$$
\begin{aligned}
& M C V=\frac{H C T \times 10}{R B C} \\
& M C H=\frac{H G B}{R B C} \\
& M C H C=\frac{H G B \times 100}{H C T}
\end{aligned}
$$

\section{Statistical Analysis}

Two-way analysis of variance (ANOVA) was employed to understand the significance of the effects of pollution levels on the haematological parameters of the fish. Post-hoc testing was conducted using Duncan's Multiple Range Test (DMRT), with $\mathrm{p}<0.05$. Statistical analysis was performed using version R-3.6.1 of the ' $R$ ' software environment for Microsoft Windows.

\section{RESULTS AND DISCUSSION}

\section{Result}

\section{RBC Count}

Tests indicated that neither the degree of water pollution (two-way ANOVA, $F_{3,9}=$ $0.51, p>0.05)$ nor the length of its exposure (two-way ANOVA, $F_{3,9}=0.60, p>0.05$ ) affected the RBC count of $O$. niloticus specimens. By contrast, the RBC content of the C. carpio specimens was seen to be strongly affected by variations in water quality (two-way ANOVA, $\left.F_{3,9}=3.13,{ }^{*} p<0.05\right)$, with the average RBC count increasing markedly, from $1.79 \times 10^{6} \pm 0.74$ cells $\mathrm{mm}^{-3}$ to $2.04 \times 10^{6} \pm$ 0.56 cells $\mathrm{mm}^{-3}$, after three days of exposure to slightly polluted water. For these specimens, $\mathrm{RBC}$ content was higher following exposure to fairly and heavily polluted water. However, RBC content decreased as the length of exposure increased (two-way ANOVA, $F_{3,9}=$ $3.47, * p<0.05$ ), with the average amount after 14 days of treatment dropping below the average on the first day $\left(2.3 \times 10^{6} \pm 0.28\right.$ cells 
$\mathrm{mm}^{-3}$ on day 0 and $2.1 \times 10^{6} \pm 0.21$ cells $\mathrm{mm}^{-3}$ on day 14).

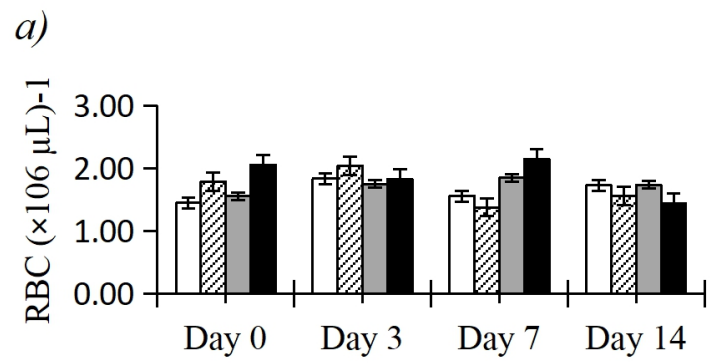

\section{$\square$ Good Water $\square$ Slightly Polluted \\ $\square$ Fairly Polluted $\quad$ Heavily Polluted}

b)

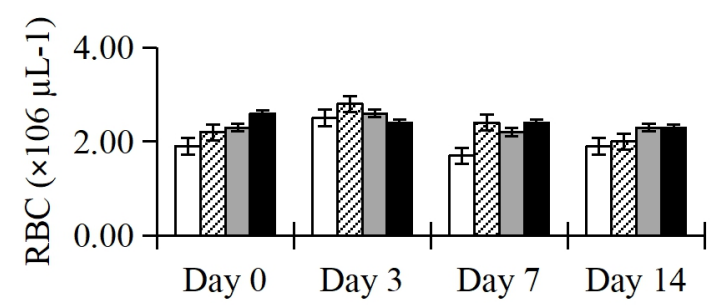

\section{$\square$ Good Water $\square$ Slightly Polluted \\ $\square$ Fairly Polluted $\square$ Heavily Polluted}

Figure 2. The average RBC counts record for $O$. niloticus (a) and C. carpio (b) specimens upon exposure to various levels of Citarum water pollution over a 14-day period.

\section{HGB Amount}

While polluted water tended to decrease HGB amounts in $O$. niloticus specimens, the decreases were not significantly affected by the degree of water contamination (two-way ANOVA, $\left.F_{3,9}=0.82, p>0.05\right)$. In contrast, increasing lengths of exposure were clearly seen to result in decreased fish HGB levels (two-way ANOVA, $F_{3,9}=8.46,{ }^{* *} p<0.01$ ). This effect was particularly evident when comparing specimens subjected to 14 days of exposure, in which average HGB was measured at $5.78 \pm 0.99 \mathrm{G} \%$, with specimens at day 0 of exposure, which recorded an average HGB rate of $9.04 \pm 2.41 \mathrm{G} \%$. Similarly, in C. carpio, HGB amounts were not affected by changes in the degree of water pollution (two-way ANOVA, $\left.F_{3,9}=0.72, p>0.05\right)$ but were affected by increasing exposure durations (two-way ANOVA, $F_{3,9}=3.84, * p<0.05$ ) (Figure 3). In this case, average fish HGB was measured as $9.2 \pm 0.60 \mathrm{G} \%$ on day 0 of exposure and as 10.1 $\pm 1.16 \mathrm{G} \%$ and $8.8 \pm 1.45 \mathrm{G} \%$ on days 7 and 14 , respectively.
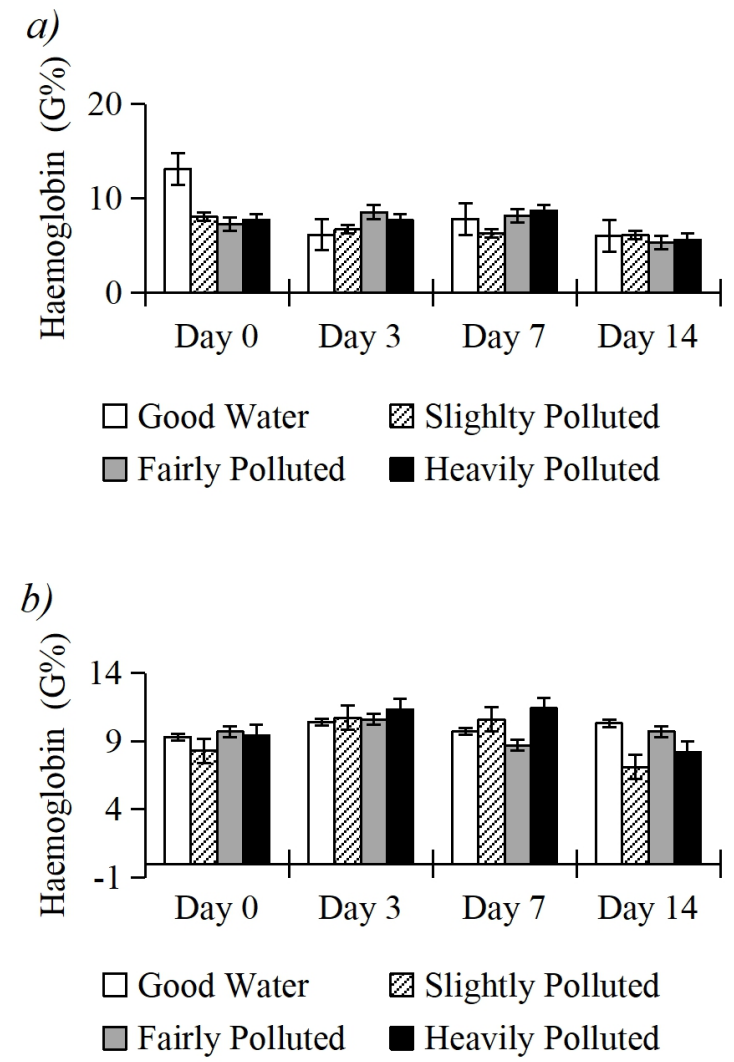

Figure 3. Average HGB, measured as $\mathrm{G} \%$, of the O. niloticus (a) and C. carpio (b) specimens upon exposure to various levels of Citarum water pollution over a 14-day period.

\section{HCT composition}

In contrast to the results of the previous two measurements, the HCT composition of $O$. niloticus specimens was not affected by either water pollution level (two-way ANOVA, $F_{3,9}=$ $0.92, p>0.05)$ or exposure length (two-way ANOVA, $F_{3,9}=1.02, p>0.05$ ). In the case of $C$. carpio, HCT composition changed significantly as a result of the length of exposure (two-way ANOVA, $\left.F_{3,9}=6.71, * * p<0.01\right)$ the average value of $23.1 \pm 3.47 \%$ on day 0 of treatment was seen to increase to $32.5 \pm 1.07 \%, 28.3 \pm$ $5.53 \%$, and $28.9 \pm 5.04 \%$ on days 3,7 and 14 , respectively. Conversely, this parameter did not change significantly as the level of water pollution increased (two-way ANOVA, $F_{3,9}=$ 2.14, $p>0.05$ ) (Figure 4), being measured at $28.7 \pm 3.28 \%$ for specimens in clean water and 
$31.1 \pm 3.66 \%$ for specimens in heavily polluted water.

a)

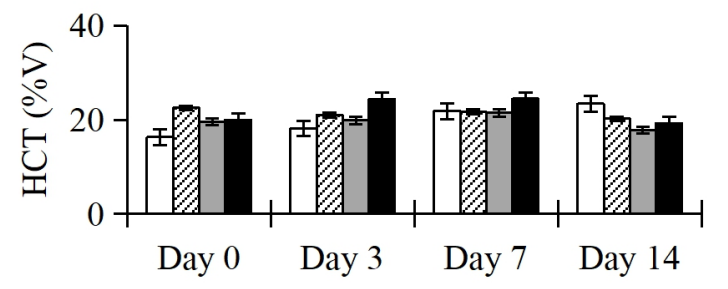

$\square$ Good Water $\square$ Slighlty Polluted
$\square$ Fairly Polluted $\quad$ Heavily Polluted

b)

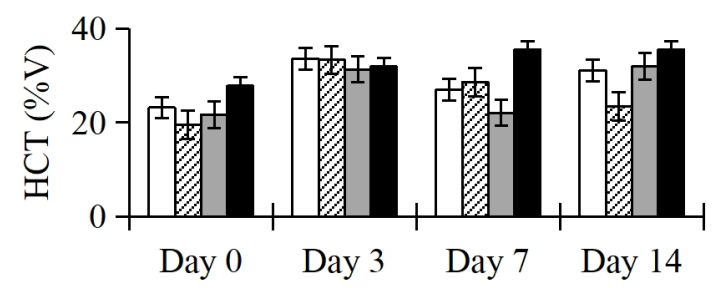

\section{$\square$ Good Water $\square$ Slightly Polluted $\square$ Fairly Polluted $\quad$ Heavily Polluted}

Figure4. The average HCT values of $O$. niloticus (a) and C. carpio (b) specimens exposed to various levels of Citarum water pollution over a 14-day period.

\section{MCV value}

$\mathrm{MCV}$ is associated with red blood cell indices and is an important indicator of the normal functioning of the same cells. In $O$. niloticus, MCV did not change significantly with changes in the degree of water pollution (two-way ANOVA, $F_{3,9}=0.76, p>0.05$ ) and the length of exposure (two-way ANOVA, $F_{3,9}=$ $1.42, p>0.05)$. The average MCV of $O$. niloticus specimens taken from the clean water experiment was $103.95 \pm 20.37 \mathrm{fL}$. Conversely, the average MCV of $C$. carpio specimens changed markedly with changes in exposed water quality (two-way ANOVA $F_{3,9}=$ $4.12, * p<0.05)$. Specifically, the MCV of carp exposed to polluted water was lower than the $148.4 \pm 17.87 \mathrm{fL}$ value recorded for those exposed to clean water. At the same time, the MCV of the carp was not significantly affected by the duration of exposure (two-way ANOVA, $F_{3,9}=2.80, p>0.05$ ) (Figure 5).

a)

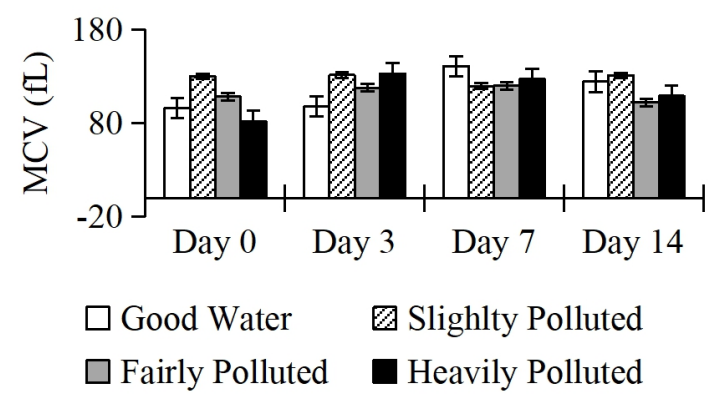

b)

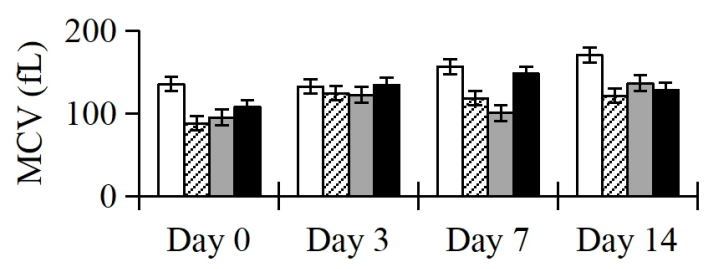

Figure 5. Average $\mathrm{MCV}$ of $O$. niloticus (a) and C. carpio (b) specimens exposed to various levels of Citarum water pollution over a 14-day period.

\section{MCH value}

The MCH levels of $O$. niloticus specimens were found to be reduced significantly by both exposure to polluted water (two-way ANOVA, $\left.F_{3,9}=3.63, * p<0.05\right)$ and increased exposure length (two-way ANOVA, $F_{3,9}=5.56,{ }^{*} p<0.05$ ). For example, in the case of exposure to clean water, fish $\mathrm{MCH}$ was recorded as $49.5 \pm 23.55$ $\rho g$ cell $^{-1}$ on average, a value that was seen to drop to $38.03 \pm 6.91 \mathrm{gg}$ cell $^{-1}$ for specimens exposed to slightly polluted water. In the case of increasing exposure length, the average fish $\mathrm{MCH}$ of $50.4 \pm 23.15 \rho \mathrm{g}$ cell $^{-1}$ on day 0 was seen to be reduced after 3 days of testing. Meanwhile, the $\mathrm{MCH}$ of $C$. carpio specimens was also significantly affected by exposure to polluted water (two-way ANOVA, $F_{3,9}=$ $3.54, * p<0.05)$, but was not affected by the length of exposure (two-way ANOVA, $F_{3,9}=$ $0.45, p>0.05$ ) (Figure 6). The MCH of this second group of carp was $52.3 \pm 5.71 \mathrm{\rho g}$ cell $^{-1}$ for clean water exposed specimens and 
decreased to between $41.8 \pm 1.00$ and $39.6 \pm$ $3.02 \mathrm{gg} \mathrm{cell}^{-1}$ as a result of exposure to various degrees of polluted water.

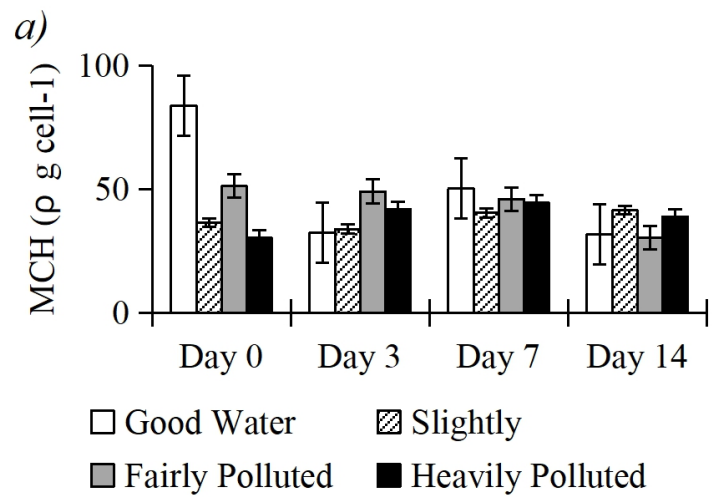

b)

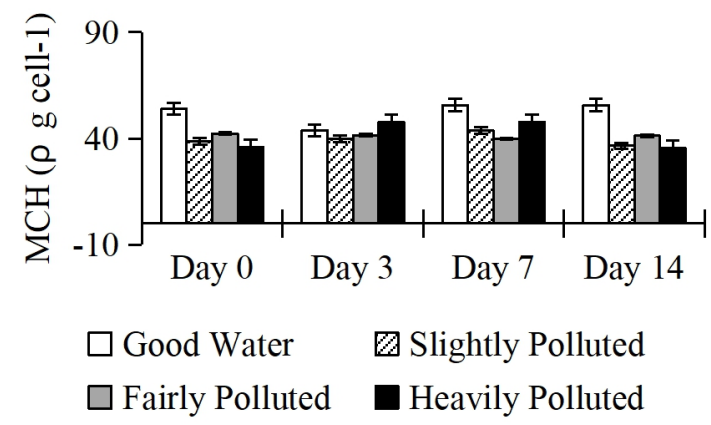

Figure 6. The average $\mathrm{MCH}$ values of $O$. niloticus (a) and C. carpio (b) specimens exposed to various levels of Citarum water pollution over a 14-day period.

\section{MCHC value}

The MCHC of the $O$. niloticus specimens, in a similar trend to $\mathrm{MCH}$ response, decreased markedly as a result of exposure to all levels of polluted water (two-way ANOVA, $F_{3,9}=$ $\left.10.67,{ }^{*} p<0.01\right)$ and as a consequence of the length of exposure (two-way ANOVA, $F_{3,9}=$ $13.2,{ }^{* *} p<0.01$ ) (Figure. 6). The MCHC of fish exposed to clean water was found to be $47.4 \pm 27.97 \mathrm{~g} \mathrm{dL}^{-1}$ on average, and exposure to polluted water reduced this value to $33.3 \pm 5.14$ $\mathrm{g} \mathrm{dL}^{-1}$ in the lowest case. In terms of the length of exposure, while on day 0 average fish $\mathrm{MCHC}$ was recorded as $52.8 \pm 24.45 \mathrm{~g} \mathrm{dL}^{-1}$ this figure shrank as a function of exposure length. In contrast, $C$. carpio $\mathrm{MCHC}$ was not affected by exposure to polluted water (two-way ANOVA, $\left.F_{3,9}=1.35, p>0.05\right)$. In this latter species of carp, however, MCHC varied widely in response to the length of exposure (two-way ANOVA, $F_{3,9}=4.77, * * p<0.01$ ), dropping to $33.8 \pm 1.35 \mathrm{~g} \mathrm{dL}^{-1}$ on average after 3 days and continuing to fall as the length of exposure increased.
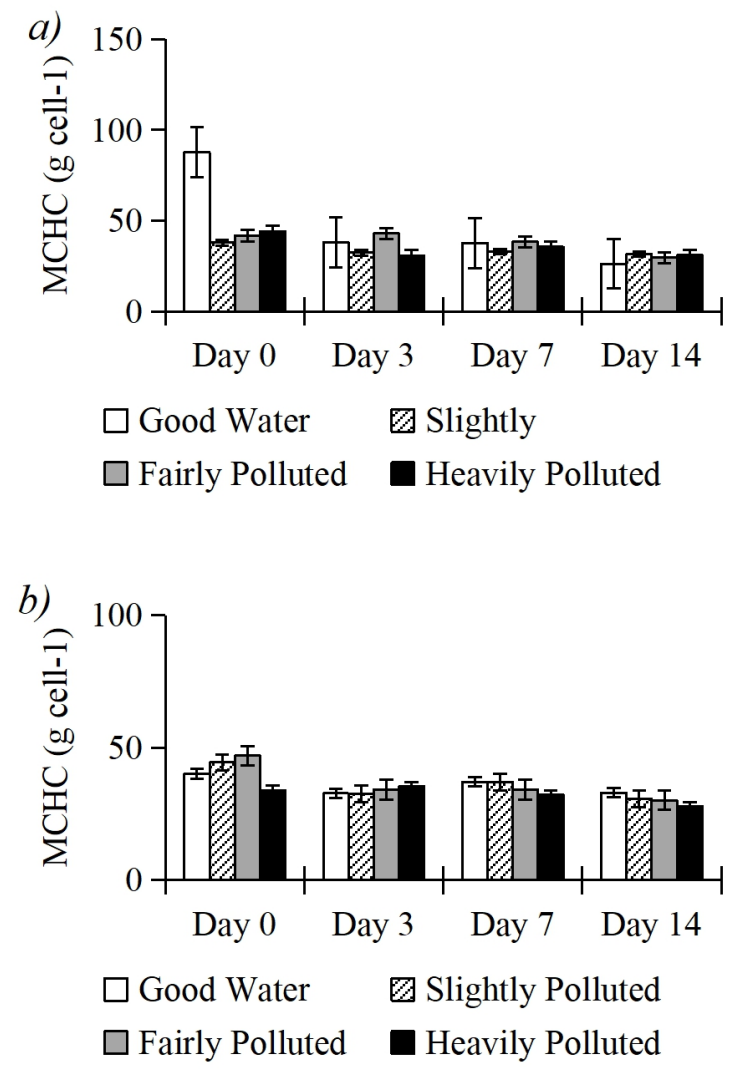

Figure 7. The average MCHC values of $O$. niloticus (a) and C. carpio (b) specimens exposed to various levels of Citarum water pollution over a 14day period.

\section{WBC Count}

WBC counts in $O$. niloticus specimens did not change significantly in response to exposure to polluted water (two-way ANOVA, $F_{3,9}=$ $1.76, p>0.05)$ but did change as a function of exposure length (two-way ANOVA, $F_{3,9}=$ $30.37, * * p<0.01)$. The WBC count of the fish was $244.8 \times 10^{9} \pm 63.16$ cells $\mathrm{L}^{-1}$ on average on the initial day of testing but decreased to $56.8 \mathrm{x}$ $10^{9} \pm 14.96$ cells $\mathrm{L}^{-1}$ and $51.9 \times 10^{9} \pm 13.80$ cells $\mathrm{L}^{-1}$ on the $7^{\text {th }}$ and $14^{\text {th }}$ day, respectively. For the $C$. carpio specimens, WBC counts increased as a consequence of both exposure to polluted water (two-way ANOVA, $F_{3,9}=$ $\left.5.19,{ }^{* *} p<0.01\right)$ and increasing length of exposure (two-way ANOVA, $F_{3,9}=7.70,{ }^{* *} p<$ 0.01) (Figure 8). Exposure to polluted water 
increased the average fish WBC count markedly, from $22.0 \times 10^{9} \pm 10.41$ cells $\mathrm{L}^{-1}$ in the clean water test to $28.7 \times 10^{9} \pm 8.39,31.9 \times$ $10^{9} \pm 7.25$ and $32.6 \times 10^{9} \pm 8.04$ cells $\mathrm{L}^{-1}$ in the tests involving slightly polluted, fairly polluted and heavily polluted water, respectively. In the case of length of exposure, WBC counts were seen to increase in the specimens after 3 days of testing.

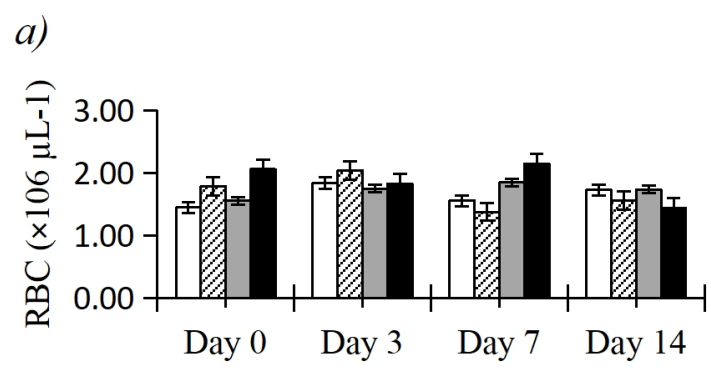

\section{$\square$ Good Water $\square$ Slightly Polluted \\ $\square$ Fairly Polluted $\quad$ Heavily Polluted}

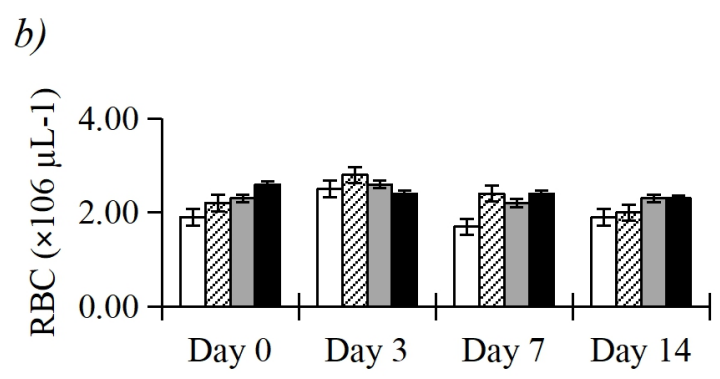

$\square$ Good Water $\square$ Slightly Polluted

$\square$ Fairly Polluted $\square$ Heavily Polluted

Figure 8. The average WBC counts of $O$. niloticus (a) and C. carpio (b) specimens exposed to various levels of Citarum water pollution over a 14-day period.

\section{Glucose level}

In the $O$. niloticus specimens, glucose levels were not altered significantly after exposure to the three different levels of water pollution (two-way ANOVA, $F_{3,9}=0.06, p>0.05$ ). As a consequence of exposure length, however, a significant change in blood glucose levels was observed for specimens subjected to polluted water for 14 days (two-way ANOVA $F_{3,9}=$ $4.44, * p<0.05)$. Glucose levels in these specimens were found to have dropped, on average, to $23.07 \pm 5.97 \mathrm{mg} \mathrm{L}^{-1}$ from an initial average value of $36.14 \pm 19.78 \mathrm{mg} \mathrm{L}^{-1}$ on day 0 . Meanwhile, the blood glucose levels in the $C$. carpio specimens were not significantly affected by either the degree of water pollution (two-way ANOVA, $F_{3,9}=0.15, p>0.05$ ) or the length of exposure (two-way ANOVA, $F_{3,9}=$ $2.56, p>0.05$ ) (Figure 9).

a)

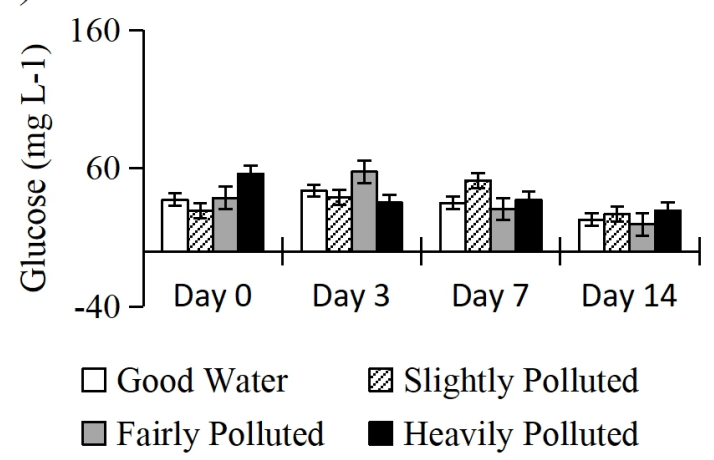

b)

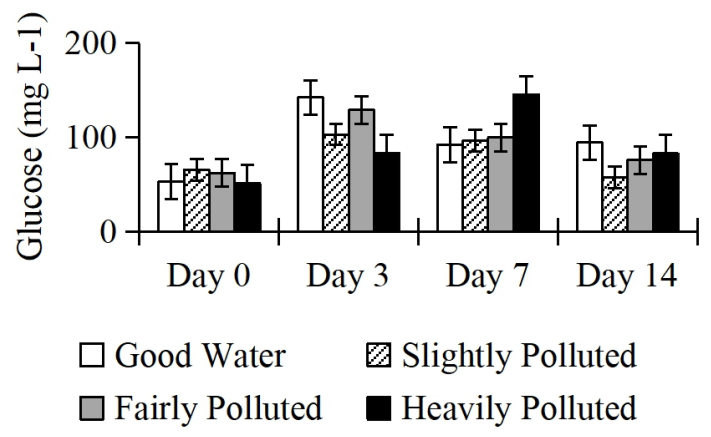

Figure 9. The blood glucose levels of $O$. niloticus (a) and C. carpio (b) specimens exposed to various levels of Citarum water pollution over a 14-day period.

\section{Discussion}

River ecosystems are hugely important because of the biodiversity they contain and the resources they deliver. Unfortunately, little attention has been paid to river conservation. River environments are exposed to a variety of stressors as a result of absorbing numerous contaminants from sources such as industry, agricultural runoff, municipal wastewater, and mining. Aquatic organisms can be affected at all levels of the biological organisation by these stressors (Gerber et al., 2018; Schäfer and Bundschuh, 2018). Halstead et al., (2014) suggested that, in most situations, stressors, 
such as river contaminants, may indirectly affect higher levels of the ecosystem hierarchy and directly affect molecular and cellular level processes. Poisoning from contaminants in the environment may result in physiological disturbances in organisms, or even in their death (Dal'Bó et al., 2015).

In the case of the Citarum River, rapid sectoral development in the catchment area has resulted in severe pollution, with agriculture, industry, and human settlement along the river increasing in line with a booming population. The Citarum River is notorious for its poor water quality and has been ranked among the most polluted rivers in the world (ADB, 2013; Cavelle, 2013). Parikesit et al. (2005) have demonstrated large site-to-site variations in water qualities and pollutant loads in the river, the latter being derived from human activities such as agriculture and the textile industry. These circumstances provide ample evidence that aquatic organisms and the river ecosystem as a whole are at risk. Iskandar (2014) indicated that fish biodiversity in the Citarum River has declined due to water pollution. Sunardi et al., (2012) confirmed that the habitats of the Citarum River can be divided into two categories: good and polluted; and that these categories influence the distribution of fish in the river. This variation in fish distribution implies a conformation of fish physiological ranges to optimum homeostasis environments; a tendency that prevails because fish not tolerant of a given level of pollution fail to adapt and, later, disappear from the river.

Dal'Bó et al., (2015) suggested that blood parameters could provide reliable information to diagnose and describe the general health conditions of fish. The study aims to confirm if the complex mixture of river contaminants poses a stressed situation to both tolerant and sensitive fish, while also investigating if they differ in response to it. The results reported in this study have demonstrated that both pollution tolerant and sensitive fish in the Citarum River are threatened by anthropogenic water contamination. The haematological indicators of both groups of fish were, to some degree, placed under stress by exposure to polluted river water. Some components of the RBC indices of $O$. niloticus and $C$. carpio showed similar changes in response to water pollution exposure. With reference to certain $\mathrm{RBC}$ indices, such as $\mathrm{MCV}, \mathrm{MCH}$, and $\mathrm{MCHC}$, fish were thought to be suffering anaemia due to the toxic effects of polluted water. Previous studies have shown that anemia is a common response to environmental stressors, particularly after long periods of exposure (Witeska, 1998; Jezierska and Witeska, 1999)In the present study, although certain fish blood parameters, such as RBC and HCT, were seen to increase and compensate for stressed homeostatic capacity, both the tolerant and sensitive fish failed to maintain a steady state. The observed responses were thought to be adaptive changes, enabling higher energy production in the organisms.

Stress reactions in fish have been shown to include increases in energetic substrate concentrations, such as glucose (Petitjean et al., 2019). Blood glucose concentration has further been shown to be a sensitive indicator of the physiological stress associated with chemical pollutants, including pesticides (Banaee, 2012). In the case of the $O$. niloticus and C. carpio specimens studied in this work, there was a tendency for blood glucose levels to increase, albeit by insignificant amounts. Even so, the elevation of blood glucose levels in fish specimens exposed to greater degrees of water pollution indicated that $C$. carpio mobilised greater levels of glucose to produce the energy required to combat the stress.

Environmental stressors have been shown to cause general physiological changes in fish that include changes to blood composition and immune system mechanisms (Witeska, 2005). Thus, besides changes in blood parameters, fish specimens exposed to polluted Citarum River water as part of this study also exhibited changes to their immune systems. This was particularly obvious for $C$. carpio specimens, in which WBC count was seen to increase as a function of increasing water pollution. These results suggest that fish develop a defensive mechanism to overcome toxic stress. Increasing or decreasing numbers of WBCs have been shown to be a normal reaction to toxicant exposure (Kori-Siakpere et al., 2006) and have been described as the result of immune system activation in the presence of a contaminant. This reaction has in turn been understood as an adaptive response of organisms that results in a more effective immune defence (BarretoMedeiros et al., 2005). 
When the two species investigated in this study were compared, a difference in response to water pollution was observed. Exposure to polluted water seemed to have more pronounced effects on the haematological activities of $C$. carpio, which, when compared to $O$. niloticus, displayed more extensive changes in blood parameters. Specifically, marked changes occurred in the RBC count, HGB, HCT, MCV, MCH, MCHC, and WBC count, of $C$. carpio. After longer lengths of exposure to polluted water, changes in $\mathrm{RBC}$ count, HGB, HCT, and WBC count were particularly apparent. Conversely, fewer blood parameters changed in O. niloticus in response to polluted water exposure, though certain obvious changes were observed in $\mathrm{HGB}, \mathrm{MCH}$, MCHC, WBC count, and blood glucose levels. Fish display a wide variation in their physiological responses to stress (Barton, 2002), and the effects of environmental toxicants on the haematological parameters of fish vary depending on the species (Elahee and Bhagwant, 2007). With reference to RBC indices, the results presented here suggest that the haematological physiology of C. carpio is more susceptible to water pollution-induced toxic stress. The greater increase in WBC count observed in this species, when compared with the more pollution tolerant $O$. niloticus, indicates its more pronounced defensive reaction to the presence of environmental contaminants.

\section{CONCLUSIONS}

Water pollution was shown to pose stress, to some degree, on the blood physiology of both tolerant and sensitive fish. While disturbances to haematological processes and immune mechanisms seemed to be a common stress response to environmental contaminants in both species, the degree of stress response differed. The more sensitive fish species were more susceptible to environmental stressors, indicating an inferior ability to cope with a stressful environment. These results also imply that the extinction rate of different fish varies in nature; namely, more sensitive fish have a higher rate of extinction.

\section{ACKNOWLEDGEMENTS}

The authors thank Dr. Keukeu Kaniawati and Dr. Tri Dewi K. Pribadi for their assistance with sampling during fieldwork and all members of the Ecotoxicology and Aquatic Ecology laboratory for their support during manuscript preparation. This research received no specific grant from any funding agency in the public, commercial, private, or not-forprofit sectors.

\section{REFERENCES}

ADB, TWB. 2013. Downstream impacts of water pollution in the Upper Citarum River, West Java, Indonesia: Economic assessment of interventions to improve water quality. Water and Sanitation Program: Technical Paper. Asian Development Bank (ADB) and The International Bank.

Amin KA, Hashem KS. 2012. Deltamethrin-induced oxidative stress and biochemical changes in tissues and blood of catfish (Clarias gariepinus): antioxidant defense and role of alpha-tocopherol. BMC Veterinary Research, $8(1), 1-8$.

APHA. 2005. WPCF (2005) Standard methods for the examination of water and wastewater. USA Washingt. DC, USA.

Balasch JC, Tort L. 2019. Netting the stress responses in fish. Frontiers in Endocrinology, 10,62 .

Banaee M. 2012. Adverse effect of insecticides on various aspects of fish's biology and physiology. Insecticides-Basic and Other Applications, 6, 101-126.

Barreto-Medeiros JM, Feitoza EG, Magalhães K, Da Silva RR, Manhães-de-Castro FM, Manhãesde-Castro R, De-Castro C. 2005. The expression of an intraspecific aggressive reaction in the face of a stressor agent alters the immune response in rats. Brazilian Journal of Biology, 65(2), 203-209.

Barton BA. 2002. Stress in fishes: a diversity of responses with particular reference to changes in circulating corticosteroids. Integrative and Comparative Biology, 42(3), 517-525.

Borgwardt F, Robinson L, Trauner D, Teixeira H, Nogueira AJA, Lillebø AI, Piet G, Kuemmerlen M, O’Higgins T, McDonald H. 2019. Exploring variability in environmental impact risk from human activities across aquatic ecosystems. Science of The Total Environment, 652, 1396-1408.

Bukola D, Zaid A, Olalekan EI, Falilu A. 2015. Consequences of anthropogenic activities on 
fish and the aquatic environment. Poultry, Fisheries \& Wildlife Sciences, 3, 138.

Cavelle J. 2013. A Political Ecology of the Citarum River Basin: Exploring" Integrated Water Resources Management" in West Java, Indonesia. Berkeley Undergraduate Journal. 26 (1), 86-107.

Chanpiwat P, Sthiannopkao S. 2013. Trace metal contamination in Southeast Asian rivers. $A P N$ Sci. Bull. 3, 6-11.

Dal'Bó GA, Sampaio FG, Losekann ME, de Queiroz JF, Luiz AJB, Wolf VHG, Gonçalves VT, Carra ML. 2015. Hematological and morphometric blood value of four cultured species of economically important tropical foodfish. Neotropical Ichthyology, 13 (2), 439446.

Elahee KB, Bhagwant S. 2007. Hematological and gill histopathological parameters of three tropical fish species from a polluted lagoon on the west coast of Mauritius. Ecotoxicology and Environmental Safety, 68(3), 361-371.

García-Nieto E, Juárez-Santacruz L, GarcíaGallegos E, Tlalmis-Zempoalteca J, RomoGómez C, Torres-Dosal A. 2014. Genotoxicological response of the common carp (Cyprinus carpio) exposed to spring water in Tlaxcala. Bulletin of Environmental Contamination and Toxicology, 93(4), 393398.

Gerber R, Smit NJ, van Vuren JHJ, Ikenaka Y, Wepener V. 2018. Biomarkers in tigerfish (Hydrocynus vittatus) as indicators of metal and organic pollution in ecologically sensitive subtropical rivers. Ecotoxicology and Environmental Safety 157, 307-317.

Gerber R, Wagenaar GM, Smith W, Ikenaka Y, Smit NJ. 2017. Insights into the drivers of histopathological changes and potential as bioindicator of riverine health of an aquatic apex predator from a premier conservation area: a multiple lines of evidence and multivariate statistics approach. Ecological Indicators, 72, 530-544.

Halpern BS, Frazier M, Potapenko J, Casey KS, Koenig K, Longo C, Lowndes JS, Rockwood RC, Selig ER, Selkoe KA. 2015. Spatial and temporal changes in cumulative human impacts on the world's ocean. Nature Communications, 6(1), 1-7.

Halstead NT, McMahon TA, Johnson SA, Raffel TR, Romansic JM, Crumrine PW, Rohr JR. 2014. Community ecology theory predicts the effects of agrochemical mixtures on aquatic biodiversity and ecosystem properties. Ecology Letters, 17(8), 932-941.

Jezierska B, Witeska M. 1999. The effect of time and temperature on motility of spermatozoa of common and grass carp. Electronic Journal of Polish Agricultural Universities. Series Fisheries, 2 (02), 1-8.

Kartamihardja ES. 2019. Degradasi Keanekaragaman Ikan Asli di Sungai Citarum, Jawa Barat. Warta Iktiologi, 3(2), 1-8.

Kori-Siakpere O, Ake JEG, Avworo UM. 2006. Sublethal effects of cadmium on some selected haematological parameters of heteroclarias (a hybrid of Heterobranchus bidorsalis and Clarias gariepinus). International Journal Zoological Research. 2, 77-83.

Lataretu A, Furnaris F, Mitranescu E. 2013. Hematologic profile as stress indicator in fish. Scientific Works. Series C. Veterinary Medicine, 59(1), 102-104.

Munir T, Hussain M, Naseem S. 2016. Water Pollution-A Menace of Freshwater Biodiversity: A Review. Journal of Entomology and Zoology Studies, 4 (4), 578580 .

Nemerow NL, Sumitomo H. 1970. Benefits of water quality enhancement report no. 16110 DAJ, prepared for the US Environmental Protection Agency.

Parikesit P, Salim H, Triharyanto E, Gunawan B, Sunardi S, Abdoellah O, Ohtsuka R. 2005. Multi-source water pollution in the Upper Citarum watershed, Indonesia, with special reference to its spatiotemporal variation. Environmental Sciences: an International Journal of Environmental Physiology and Toxicology, 12(3), 121-131.

Petitjean Q, Jean S, Gandar A, Côte J, Laffaille P, Jacquin L. 2019. Stress responses in fish: From molecular to evolutionary processes. Science Total Environment. 684, 371-380.

Rebouças VT, dos Santos Lima FR, de Holanda Cavalcante D. 2015. Tolerance of Nile tilapia juveniles to highly acidic rearing water. Acta Scientiarum. Animal Sciences, 37(3), 227-233.

Schäfer RB, Bundschuh M. 2018. Ecotoxicology, in: Riverine Ecosystem Management. Springer, pp. 225-239.

Sunardi, Kaniawati K, Husodo T, Malini DM, Astari AJ. 2012. Distribution of Fish in the Upper Citarum River: an Adaptive Response to Physico-Chemical Properties. Hayati Journal of Biosciences 19, 191-196. 
Turgeon ML. 2005. Clinical Hematology : Theory and Procedures. USA: Williams and Wilkins.

UNESCO. 2012. Citarum River Basin water quality improvement through demonstration of innovative technologies and enhancing capacities at the community, river basin and national levels. Available: http://www.switchin-asia.org/Pilot sites/SWITCH - Citarum River concept note NOV2012 EN.pdf.

Vicente IST, Fonseca-Alves CE. 2013. Impact of introduced Nile tilapia (Oreochromis niloticus) on non-native aquatic ecosystems. Pakistan Journal of Biological Sciences: PJBS, 16(3), 121-126.

Witeska M. 2005. Stress in fish-hematological and immunological effects of heavy metals. Electronic Journal of Ichthyology, 1, 35-41.
Witeska M. 1998. Changes in selected blood indices of common carp after acute exposure to cadmium. Acta Veterinaria Brno, 67(4), 289293.

Woodman DA. Tharp GD. 2002. Experiments in Physiology. Prentice Hall.

Responding to Global Changes: The Water Quality Challenge -Prevention, Wise Use and Abatement. World Water Week in Stockholm. Available:

http://www.worldwaterweek.org/documents/R esources/Synthesis/Abstract Volume 2010.pd f. 